\title{
Riddling Words: the Prophetiae Merlini
}

\author{
Maud Burnett McInerney
}

In Shakespeare's Henry IV, Henry Percy, better known as Hotspur, complains to Mortimer about their co-conspirator, Owen Glendower:

\section{Sometimes he angers me}

With telling me of the moldwarp and the ant

Of the dreamer Merlin and his prophecies ...

And such a deal of skimble skamble stuff.

Henry IV Part I, III.1.143-49

For Hotspur, Merlin's prophecies are hogwash, inseparable both from Owen's pretentions and from his superstitious Welshness. In the context of Shakespeare's play, they are also, quite simply, false: for all that he boasts of omens, of "fiery shapes / of burning cressets" and earthquakes at his birth, Owen Glendower did not prove to be the long-awaited king who would restore the independence of the Welsh. He escaped the fate of Percy, whose head would hang on London Bridge as witness to his treachery, but only to fade out of history, his date and place of death unknown. ${ }^{1}$ Shakespeare's mockery of the Prophetiae Merlini, however, only testifies to the extraordinary tenacity of their hold upon the British imagination, some three and a half centuries after they were composed by Geoffrey of Monmouth. In the intervening centuries, the prophecies had taken on a life of their own, circulating independently of the De gestis Britonum ${ }^{2}$ and revised and reimagined for every possible purpose in England, Wales, and beyond. Many of Geoffrey's contemporaries and successors believed in the prophecies, or wanted to, either as revealed truth or as useful political tools, and much critical energy has been devoted to unmasking such Galfridian curiosities as the boar of trade, the old man in white on

1 On Owain Glyn Dŵr, see G.A. Williams, The Last Days of Owain Glyndŵr, Talybont, 2017 and I. Mortimer, "The Great Magician", in id. (ed.), The Fears of Henry IV: The Life of England's Self-Made King, London, 2007, pp. 226-43. For Owain Glyn Dŵr's own use of prophecy, see R.R. Davies, The Revolt of Owain Glyn Dîrr, Oxford, 1995, pp. 156-61.

2 According to Julia Crick, no fewer than 76 independent manuscripts of the $P M$ exist; see Crick, $S C$, pp. $33^{-}-32$. 
the snow-white horse, or the city-building hedgehog. ${ }^{3}$ In the pages that follow, I argue that such attempts are largely futile (though they would no doubt have delighted Geoffrey); rather, given the always dubious status of Geoffrey's sources, the function of the $P M$ is literary as much as it is political. As Lesley Coote points out, "prophecy is not a genre but a discourse" with the capacity to operate independently of the intent of its author or the desires of its readers. ${ }^{4}$ Not only does the $D G B$ as a whole manifest considerable anxiety about the reliability of prophecy, but the primary operation of prophecy within a text that purports to be history is to create a complex narrative temporality which claims access to past, present, and future. In the creation of such a temporality, Geoffrey is perhaps closer to his great inspiration, Virgil, than to any of his contemporaries. ${ }^{5}$

Medieval prophecy was rooted in both pagan and Judeo-Christian traditions. From the classical tradition, medieval authors adopted the all-knowing Sibyl from the sixth book of Virgil's Aeneid; like Virgil himself, who was believed to have predicted the advent of Christ in the fourth Eclogue, the Sibyl became an example of pagan prophecy predicting Christian truth. ${ }^{6}$ The Bible provided not only the examples of Isaiah, Jeremiah, Daniel, Ezekiel and the so-called minor prophets, but was understood to be inherently prophetic in the sense that the Old Testament predicted the New and the New looked forward to the end of times and the establishment of the kingdom of God on earth. The single most important prophetic text of the Middle Ages was the Revelation of John, which, in the later half of the 12th century, would be enthusiastically channeled by the works of Hildegard of Bingen and Joachim of Fiore. Apocalyptic prophecy always had a political element to it - Joachim himself identified a panoply of antichrists past and present, from Herod and Nero to Saladin - but its primary focus was eschatological: it looked beyond this world and into the next. ${ }^{7}$ Geoffrey of Monmouth's prophecies differ in that they are secular rather than religious; while he may draw images from Revelation and other religious texts, his $P M$ stand at the beginning of what Rupert Taylor, in 1911, identified as a tradition of primarily political prophecy in England. ${ }^{8}$

3 DGB, Prophetiae 115.129, 115.108-o9, 116.172, respectively.

4 L.A. Coote, Prophecy and Public Affairs in Later Medieval England, Woodbridge, 20oo, p. 13.

5 See Paul Russell's chapter in this volume.

6 See P. Dronke, "Medieval Sibyls: Their Character and their 'Auctoritas', Studii Medievali 36:2 (1994), 581-615, at pp. 6o8-o9.

7 E.R. Daniel, “Joachim of Fiore's Apocalyptic Scenario", in C.W. Bynum and P. Freedman (eds.), Last Things: Death and the Apocalypse in the Middle Ages, Philadelphia, 2000, pp. 124-39. On the multiplicity of antichrists, see R.E. Lerner, "Antichrists and Antichrist in Joachim of Fiore", Speculum 6o:3 (1985), 553-70, at pp. 562-63.

8 R. Taylor, The Political Prophecy in England, New York, 1911; see pp. 27-38 for Taylor's account of the classical and biblical sources of Geoffrey's prophecies. 
Geoffrey identifies the $P M$, which comprise Book VII of the $D G B,{ }^{9}$ as a digression from the central narrative, one imposed upon him by an eager public. In the middle of his account of the reign of the usurper Vortigern, he inserts the following statement: "Before I had reached this point in my history, news of Merlin spread and I was being pressed to publish his prophecies by all my contemporaries, and particularly by Alexander bishop of Lincoln, a man of the greatest piety and wisdom." ${ }^{10}$ As in the case of the $D G B$ itself, Geoffrey here claims to be translating the prophecies from a language unknown to Alexander (ignotum tibi ... sermonum, "a tongue ... unknown to you"). ${ }^{11}$ The impression he creates is that the scholarly community was in an uproar about the $P M$, inaccessible to the Latinate but French- and English-speaking scholars of Oxford and Lincoln, and that Geoffrey therefore paused in his endeavors at the very moment when he should have been continuing the story of Vortigern to make a quick translation for their sake, which he drops into the larger narrative as the $P M$.

In fact, we know that the $P M$ were already in circulation several years before Geoffrey completed the $D G B$. Orderic Vitalis, an English-born monk at work upon his own history, the Ecclesiastical History, at Saint-Évroul in Normandy, saw a copy of it before the end of $1135 .{ }^{12}$ Orderic had brought his account up to his own days, describing the death of Robert Curthose, eldest son of William the Conqueror and deposed duke of Normandy. Evidently inspired to think of prophecy by Robert's prescient dream of the death of his son, Orderic followed that event with a summary of "the prophecy of Ambrosius Merlin, which he uttered in the time of Vortigern, king of Britain".13 The $D G B$ was not yet in circulation at the time, and Orderic's citation, which is often word for

In Reeve's edition, they are titled Prophetiae Merlini rather than Book VII, reflecting the original independent circulation of the prophecies.

$10 \quad D G B$, Prologus in Prophetias Merlini 109.1-4: "Nondum autem ad hunc locum historiae perueneram cum de Merlino diuulgato rumore compellebant me undique contemporanei mei prophetias ipsius edere, maxime autem Alexander Lincolniensis episcopus, uir summae religionis et prudentiae." Translations are Wright's unless otherwise noted. See M.A. Faletra, "Merlin in Cornwall: The Source and Contexts of John of Cornwall's Prophetia Merlini", JEGP 111:3 (2012), 303-38, at p. 312 for the argument that there was a pre-existing prophecy in a form of Old Cornish dating to 1070-1130. Faletra argues that John of Cornwall (who knew Cornish) certainly drew upon this in his "rich and overtly critical response" (p. 305) to the $D G B$, and that Geoffrey (who probably did not know Cornish) may also have been aware of it. See also M.J. Curley, "A New Edition of John of Cornwall's Prophetia Merlini", Speculum 57:2 (1982), 217-49.

$11 \quad D G B$, Prophetiae 110.15 .

12 See Jaakko Tahkokallio's chapter in this volume.

13 Orderic Vitalis, Ecclesiastical Historyxii.47.1-2, ed. and trans. M. Chibnall, The Ecclesiastical History of Orderic Vitalis, 6 vols., Oxford, 1969-8o, vol. 6, p. 387: "Ambrosii Merlinii prophetia quam tempore Guortigerni regis Britanniae uaticinatus est". 
word, must thus derive from Geoffrey's earlier, independent $P M .^{14}$ Orderic's own comment, toward the end of his summary, implies also that the work was not easily available; he writes that he has "taken this short extract from the book of Merlin, and ... provided a very small sample of it for scholars to whom it has not been divulged". ${ }^{15}$ How exactly the $P M$ came into his hands is unclear, but evidently he sees himself as having had rare and privileged access - thus his emphasis on other scholars who have not been so fortunate. The diminutive libellus also makes it plain that what he saw cannot have been the $D G B$ as a whole, since it could by no stretch of the imagination be described as a "little book".

Orderic's evidence makes nonsense of Geoffrey's claim that he had to put aside the longer work in order to translate the prophecies in a white heat, but it gives us little insight into the sources upon which Geoffrey may have drawn. Was Merlin indeed already a well-known figure in the early 12th century? Were rumors about him spreading? As early as 1928, James Douglas Bruce pointed out that "Merlin owes his fortune in the history of fiction and popular tradition to Geoffrey of Monmouth. He is virtually the creation of Geoffrey."16 More recently, O.J. Padel has asserted that "in Merlin's case there is no doubt but that it was Geoffrey who launched him on his international literary career."17 The figure of Merlin that Geoffrey creates is a composite, partly inspired by the boy-prophet Ambrosius from the Historia Brittonum (mid-9th century ${ }^{18}$ ), and

14 Reeve suggests that the $P M$ functioned as a sort of "trailer" for the $D G B ; D G B$, p. viii. See also Curley, "A New Edition", pp. 219-20; C.D. Eckhardt, "The Date of the Prophetia Merlini Commentary in Mss Cotton Claudius BVII and Bibliothèque Nationale Fonds Latin 6233", Notes and Queries, new series, 23 (1976), 146-47, at p. 146; J. Crick, "Geoffrey and the Prophetic Tradition", in S. Echard (ed.), The Arthur of Medieval Latin Literature: The Development and Dissemination of the Arthurian Legend in Medieval Latin (Arthurian Literature of the Middle Ages, 6), Cardiff, 2011, pp. 67-82. For the possibility that the $P M$ was circulating in some form as early as the 1120 s, see B. Meehan, "Geoffrey of Monmouth, Prophecies of Merlin: New Manuscript Evidence”, ввсs 28:1 (1978-80), 37-46.

15 Orderic Vitalis, Ecclesiastical History xii.47.493, ed. and trans. Chibnall, vol. 6, p. 386: "Hanc lectiunculam de Merlini libello excerpsi et studiosis quibus ipse propalatus non est quantulamcumque stillam propinavi."

16 J.D. Bruce, The Evolution of Arthurian Romance from the Beginnings down to the Year 1300, Baltimore, 1928 (repr. Gloucester, MA, 1958). See also P. Zumthor, Merlin le Prophète, un thème de la littérature polémique de l'historiographie et des romans, Lausanne, 1943, pp. $17-25$.

17 O.J. Padel, "Recent Work on the Origins of the Arthurian Legend: A Comment", Arthuriana 5:3 (1995), 103-14, at p. 105 .

18 The Historia Brittonum has been securely dated to 829/30: B. Guy, "The Origins of the Compilation of Welsh Historical Texts in Harley 3859", Studia Celtica 49 (2015), 21-56. 
partly by the bardic Myrddin of Welsh tradition, who appears in the 1oth century Armes Prydein Vawr ("The Great Prophecy of Britain"). ${ }^{19}$

Ambrosius's appearance in the Historia Brittonum is brief; a mysterious boy without a father (although, in typically Nennian contradictory fashion, the author later claims that his father was a Roman consul), he prophesies and then interprets the combat between two dragons, one red and one white, who are preventing the construction of King Vortigern's tower, explaining that the red dragon represents the British and the white the Saxons. Ambrosius predicts that the British will eventually drive the Saxons out of Britain, a prophecy that would become known throughout Welsh literary history as the "Omen of the Dragons" because of the ominous words pronounced by Geoffrey's Merlin Ambrosius, Vae rubeo draconi, "Alas for the red dragon". ${ }^{20}$ After this episode, which Geoffrey will expand in Book VII of the $D G B$, he disappears from the narrative.

The Welsh sources Geoffrey may have used in creating Merlin are much less clear. Four poems from the Black Book of Carmarthen (Llyfr du Caerfyrddin, Aberystwyth, National Library of Wales, Peniarth 1), copied around 1250, are attributed to Myrddin, who is imagined as a 6th-century bard; one, Ymddiddan Myrddin a Thaliesin ("The Conversation of Myrddin and Taliesin"), actually names him. ${ }^{21}$ These poems may have been in circulation in some form when

19 Armes Prydein Vawr, ed. and trans I. Williams and R. Bromwich, Armes Prydein: The Prophecy of Britain from the Book of Taliesin, Dublin, 1972. T.M. Charles-Edwards argues for a date between 927 and 994; see Wales and the Britons 350-1064, Oxford, 2013, pp. 519-35. As long ago as the 188os, G. Paris, "La Borderie, L'Historia Britonum", Romania 12 (1883), $367-76$, at p. 375 suggested plausibly that Geoffrey altered "Myrddin" to "Merlin" to avoid a name that might recall the French merde: "Ce nom est l'invention de Gaufrei de Monmouth, qui sans doute a reculé devant le Merdinus qu'il aurait obtenu en latinisant le nom gallois", "The name is the invention of Geoffrey of Monmouth, who no doubt recoiled at Merdinus, which he would have gotten by Latinizing the Welsh name."

$D G B$, Prophetiae 112.34. See, for instance, the Welsh prose text Lludd and Llefelys (dating is problematic; a fragment appears in the White Book of Rhydderch $c .135^{\circ}$, but the tale is also incorporated into a Welsh translation of the $D G B$ in Aberystwyth, National Library of Wales, Llanstephan 1 in the mid-13th century); see D. Huws, Medieval Welsh Manuscripts, Aberystwyth, 200o, p. 58 and Cyfranc Lludd and Llefelys, ed. B.F. Roberts (Mediaeval and Modern Welsh Series, 7), Dublin, 1975. The story is the origin of the Welsh flag, a red dragon on a green and white ground, which was flown by Henry Tudor before his accession as Henry ViI. On Henry as the mab darogan, "son of prophecy", see A.L. Jones, Darogan: Prophecy, Lament and Absent Heroes in Medieval Welsh Literature, Cardiff, 2013, p. 3.

21 For details of dating and provenance, see Huws, Medieval Welsh Manuscripts, pp. 70-72; see also Llyfr Du Caerfyrddin: gyda Rhagymadrodd, Nodiadau Testunol, a Geirfa [The Black Book of Carmarthen: with introduction, textual notes, and vocabulary], ed. A.O.H.Jarman, Cardiff, 1982. 
Geoffrey was writing. ${ }^{22}$ The Red Book of Hergest (Llyfr Coch Hergest, Oxford, Jesus College, 111), a collection dated to shortly after $1382,{ }^{23}$ contains three more poems associated with Myrddin, Cyfoesi Myrddin a Gwenddydd ei Chwaer ("The Prophecy of Myrddin and Gwenddydd his Sister"), Gwasgargerdd Fyrddin yn y Bedd ("The Diffused/Scattered Poem of Myrddin in the Grave"), and Peirian Faban ("Commanding Youth"). ${ }^{24}$ These poems allow for a "feasible reconstruction" of Myrddin as an exemplar of the Wild Man of the Woods, a folkloric motif at least as old as the biblical Nebuchadnezzar, according to A.O.H. Jarman. ${ }^{25}$

The dating of all of these texts, however, is problematic; nor is it clear how much of the Welsh material was familiar to Geoffrey when he was composing the $P M$, although Ben Guy argues, in an essay in this volume, that Geoffrey may have known most of them even as he was composing the $D G B .{ }^{26}$ Certainly, when he came to write the $V M$ a decade or so later, he drew on traditions concerning a mad prophet who lived in the woods. Geoffrey seems to have seen no contradiction between this figure and the magician of the $D G B$; the Merlin of the $V M$ refers to his prophecy before Vortigern. ${ }^{27}$ Gerald of Wales, however, whose suspicions about Merlin were profound, categorically denies that they can have been one and the same: "There were two Merlins. The one called Ambrosius, who thus had two names, prophesied when Vortigern was king ... The second Merlin came from Scotland ... He went mad ... and fled to

22 See N. Tolstoy, "Geoffrey of Monmouth and the Merlin Legend", $A L 25$ (2008), 1-42, at pp. 2-3 for a summary of the debate around Geoffrey's access to these materials.

23 Huws, Medieval Welsh Manuscripts, p. 82; see also id., "Llyfr Coch Hergest", in I. Daniel, M. Haycock, D. Johnston and J. Rowland (eds.), Cyfoeth y Testun: Ysgrifau ar Lenyddiath Gymraeg yr Oesoedd Canol, Cardiff, 2003, pp. 1-30.

24 Cyfoesi Myrddin is edited by M.B. Jenkins, "Aspects of the Welsh Prophetic Verse Tradition: Incorporating Textual Studies of the Poetry from 'Llyfr Coch Hergest' (Oxford, Jesus College, MS cxi) and 'Y Cwta Cyfarwydd' (Aberystwyth, National Library of Wales, MS Peniarth 50)", unpublished PhD thesis, University of Cambridge, 199o, pp. 33-9o, although I was not able to consult it for this essay; see also Peirian Vaban, ed. A.O.H. Jarman, "Peirian Vaban", ввсs 14 (1950-52), 104-08; for translations, see The Four Ancient Books of Wales Containing the Cymric Poems Attributed to the Bards of the Sixth Century, Volume I, trans. W.F. Skene, Edinburgh, 1868, pp. 218-40, and The Romance of Merlin: An Anthology, ed. P. Goodrich, New York, 199o.

25 A.O.H.Jarman, "The Merlin Legend and the Welsh Tradition of Prophecy", in R. Bromwich, A.O.H. Jarman, and B.F. Roberts (eds.), The Arthur of the Welsh: The Arthurian Legend in Medieval Welsh Literature (Arthurian Literature in the Middle Ages, 1), Cardiff, 1991, pp. 117-45, at p. 117. See also N. Thomas, "The Celtic Wildman Tradition and Geoffrey of Monmouth's Vita Merlini", Arthuriana 10:1 (2000), 27-42.

26 See Ben Guy's contribution to this volume, pp. 62-65.

27 Jarman, "The Merlin Legend", p. 132. 
the wood where he passed the remainder of his life as a wild man of the woods. This second Merlin lived in the time of Arthur."28 Gerald's comment that the "second Merlin" came from Scotland suggests some awareness of the parallel (or perhaps precursor) traditions of another wild man, the Scottish Lailoken.

Like Merlin himself, the $P M$ is very much a composite, inspired by Welsh prophetic tradition rather than directly descended from it. It is possible that Geoffrey knew Armes Prydein Vawr, the 1oth-century Welsh poem in which Myrddin appears, and which predicts the expulsion of the Saxons from Britain; the poem's reiteration of the coupled names Cynan and Cadwaladr is echoed in the $P M .{ }^{29}$ Other sources are difficult to identify, and Zumthor suggests that Geoffrey was at least as much indebted to biblical prophecy and to the legends around the Tiburtine Sibyl as he was to Welsh material. ${ }^{30}$ The related questions of Geoffrey's access to Welsh materials, his knowledge of the Welsh or Cornish languages, and his own ethnic identity have been treated extensively elsewhere, most recently in the introduction to the present volume. Regardless of his ethnicity, Geoffrey was deeply implicated in what Faletra calls "the network of Norman power"; ${ }^{31}$ he depended upon it for professional advancement within the church, at the very least. In translating or purporting to translate British prophetic material into Latin, Geoffrey was engaged in something more complicated than the glorification of an idealized British or Celtic past; medieval Celtic language speakers did not, in any case, see each other as natural allies, as their modern descendants sometimes strive to. Geoffrey operated in a 12th-century sphere of Norman political and cultural ascendance in which there circulated a lively tradition of Welsh prophecy, but the prophecies he

28 Gerald of Wales, The Journey Through Wales ii.8, ed. J.F. Dimock, Giraldi Cambrensis Opera, 8 vols., London, 1861-91, vol. 6, pp. 3-152, at p. 133: "Erant enim Merlini duo; iste qui et Ambrosius dictus est, quia binomius fuerat, et sub rege Vortigerno prophetizavit ... alter vero de Albania oriundus ... dementire coepit, et ad silvam transfugiendo silvestrem usque ad obitum vitam perduxit. Hic autem Merlinus tempore Arturi fuit", translated in Gerald of Wales, The Journey Through Wales and The Description of Wales, trans. L. Thorpe, Gerald of Wales: The Journey through Wales / The Description of Wales, Harmondsworth, 1978, pp. 192-93.

$29 D G B$, Prophetiae 115.110-11: "Cadualadrus Conanum uocabit et Albaniam in societatem accipiet", "Cadualadrus will summon Conananus and make Scotland his ally." See A.O.H. Jarman, "The Welsh Myrddin Poems", in R.S. Loomis (ed.), Arthurian Literature in the Middle Ages, Oxford, 1959, pp. 20-30; D.N. Dumville, "Brittany and Armes Prydein Vawr", Études celtiques 20 (1983), 145-59.

30 Zumthor, Merlin le Prophète, pp. 26-29. See also Paul Russell's contribution to this volume.

31 M.A. Faletra, "Narrating the Matter of Britain: Geoffrey of Monmouth and the Norman Colonization of Wales", The Chaucer Review 35:1 (2000), 60-85, at p. 62. 
places in the mouth of Merlin need not be read (although they often were, in the centuries to follow) as pro-Welsh. Rather, as Victoria Flood puts it, they perform a kind of "paranoid ventriloquism" which "anticipate[s] the terms of Welsh prophetic opposition during a period of heightened border threats" in the aftermath of the death of Henry $\mathrm{I}^{32}$ While Geoffrey does not appear to have drawn directly on pre-existing Welsh prophecies, perhaps because he did not have access to the language in which they circulated, he does incorporate into the figure of Merlin essential elements of the Welsh prophetical poet. As Williams notes, Geoffrey's Merlin is "a distinctly Taliesinic figure ... an all-knowing youth, prophesying obscurely",33 and Taliesin even appears in the $V M$, as Telgesinus. ${ }^{34}$ The essential feature of the Welsh prophet as embodied in Taliesin is that he is also a poet: Welsh prophecy was a poetic mode, expressed in a variety of more and less strict meters. ${ }^{35}$ The "continuum of identity between the figures of the poet and the prophet"36 are perhaps what license Geoffrey's revision of Virgil's Aeneid, a text to which the $P M$ is in many ways more explicitly indebted than it is to any particular Welsh work. The insertion of the $P M$ into the $D G B$ operates, in fact, not only to reconfigure the Breton or British hope for the return of Arthur in pro-Norman rather than pro-Welsh terms, but also to create a prophetic power for its author, Geoffrey himself, with roots in both Insular and Virgilian traditions.

Within the larger context of the $D G B$, the $P M$ has a problematic narrative effect. The $D G B$ declares itself as history in its opening line: "While my mind was often pondering many things in many ways, my thoughts turned to the history of the kings of Britain."37 What follows certainly looks like one kind of history; beginning with Brutus, the exiled grandson of Aeneas, Geoffrey traces the lineage of the kings of Britain down through the ages until $682 \mathrm{CE}$. The work constructs an apparently linear chronology, reign by reign, father to son (or, in some cases, daughter), until the sudden eruption of the $P M$ at the end of the sixth book. An exploration of the past is thus suddenly interrupted by an

32 V. Flood, Prophecy, Politics and Place in Medieval England: From Geoffrey of Monmouth to Thomas of Erceldoune, Cambridge, 2016, p. 35.

33 M. Williams, Fiery Shapes: Celestial Portents and Astrology in Ireland and Wales, 700-1700, Oxford, 2010, p. 77 .

34 On the possibility that the Book of Taliesin (Llyfr Taliesin) draws upon Geoffrey and not the other way around, see M. Haycock, "Taliesin's 'Lesser Song of the World", in T. Jones and E.B. Fryde (eds.), Ysgrifau a cherddi cyflwynedig i Daniel Huws. Essays and Poems Presented to Daniel Huws, Aberystwyth, 1994, pp. 229-50, at p. 243.

35 On the variations between metrical prophetic forms, see A.L. Jones, Darogan, p. 14.

36 M. Williams, Fiery Shapes, p. 76.

$37 D G B$, Prologus 1.1-2: "Cum mecum multa et de multis saepius animo reuoluens in hystoriam regum Britanniae inciderem." 
exploration of the future, a phenomenon that threatens to upset the temporality of the text thus far, transforming its focus from the (quasi-) historical past to the mystically glimpsed future.

The question "What is history?" cannot be addressed comprehensively within the scope of this essay, but it is, I hope, fair to say that, in the 21st century, history is still generally understood to have some connection to actual events of the past, to "what happened". We are often admonished to learn from the events of the past, as when the Civil Rights movement of the 196o's is invoked as precedent for the LG BTQ rights movement of the present day. Even if, postFoucault and Derrida, we are suspicious of empiricist histories that propose to tell us precisely what happened and why, and are more interested in history as discourse, in how history frames what happened, we still assume some connection between that discourse and actual events. Discipline and Punish, after all, begins with an event that actually occurred, the torture and execution of Robert-François Damiens on the Place de Grève in Paris, in 1757. For medieval historians, the foundation of history upon fact, and indeed the distinction between history and what we would call fiction, are not particularly relevant. What matters instead is the way in which both history and fiction could point toward truth. Walter Map, writing in the generation after Geoffrey, was keenly aware of the fascination with the past that characterized the time in which he wrote. In The Courtier's Trifles, he argues that

we have histories continued from the beginning down to us; we read fiction [fabulae] too; and if we understand the mystical significance of history, we then learn what ought to please us ... Admonitory stories set before us Atreus and Thyestes, Pelops and Lycaeon, and many like them, that we may shun their ends; and the utterances of history are not without their use: one is the method and intention of the story in either case. ${ }^{38}$

For Walter, the distinction between what did and did not happen is of little importance; rather, he makes the point that moral truth can be expressed in different genres; fabulae may be as exemplary as historiae. Each reveals something profound and monitory about the workings of the universe: "In narratives

38 Walter Map, The Courtiers' Trifles i.31, ed. and trans. M.R. James, revised by C.N.L. Brooke and R.A.B. Mynors, Oxford, 1983, pp. 126-28: "historias ab inicio ad nos usque deductas habemus, fabulas eciam legimus, et que placere debeant intellectu mistico nouimus ... Fabule nobis eciam commonitorie Atreum et Thiestem, Pelopem et Licaona, multosque similes eorum proponunt, ut uitemus eorum exitus, et sunt historiarum sentencie non inutiles; unus utrimque narracionum mos et intencio." 
[scripturis] adversity succeedeth in turn to prosperity and vice versa." ${ }^{39}$ As Monika Otter puts it, "a neat categorical distinction between fiction and other modes of discourse is not to be expected in twelfth century thought." 40

Even by 12th-century standards, however, a history that not only appears to have little, if any, relationship to what happened in the past, but also suddenly reverses its own temporality in order to announce what will happen in the future would be an oddity. Emerging in the middle of a document that claims to look into the deepest past, the $P M$ not only predicts the future from the perspective of those within the text, it carries on to predict a future that occurs after the ending of that narrative with the fall of Britain to the Anglo-Saxons, and then further still to a future that extends through and beyond the lifetime of the author. The immediate context of the $P M$ within the larger narrative helps explain why Geoffrey included it. After the murders of Constantinus and his son Constans, Vortigern usurps the throne. Almost immediately, the Saxon brothers Hengist and Horsa land in Kent with an imposing army. Vortigern, under threat from the Picts, offers the Saxons land in exchange for protection and marries Hengist's daughter, Ronwein. After a series of bloody struggles between Vortigern and his Saxon allies and the native British, Hengist initiates a full-scale invasion of the island, and Vortigern is driven into Wales, where his magicians advise him to build a great tower as refuge against the barbarians. Each day, however, the foundations that are laid are swallowed up by the earth. The magicians instruct Vortigern to find a boy without a father and sacrifice him so that his blood pours over the newly laid stones, promising that this will allow the building of the tower. A boy named Merlin, son of a noble mother and an incubus, is brought before Vortigern, but he challenges the king's magicians:

Without knowing what is hindering the foundation of the tower that is being built, you have advised that the cement be sprinkled with my blood, whereupon it would almost instantly stand firm. But tell me what is hidden beneath the foundations. There is something beneath which prevents the tower standing firm. ${ }^{41}$

39 Walter Map, The Courtiers' Trifles i.31, ed. and trans. James, p. 128: "sibique succedunt inuicem in scripturis tum aduersitas prosperitati, tum e conuerso mutacione frequenti."

40 M. Otter, Inventiones: Fiction and Referentiality in Twelfth-Century English Historical Writing, Chapel Hill, 1996, p. 14.

$41 D G B$, vi.108.561-64: "Nescientes quid fundamentum inceptae turris impediat, laudauistis ut sanguis meus diffunderetur in caementum et quasi ilico opus constaret. Sed dicite michi quid sub fundamento latet. Nam aliquid sub illo est quod ipsum stare non permittit." 
The magicians are confounded, and Merlin orders the king to dig down beneath the foundation, revealing a pool of water. Again he challenges the magicians to explain what lies beneath the pool, and again they fail to answer. Merlin predicts that beneath the pool two dragons will be found asleep; the king, impressed by Merlin's previous prediction, does so, and "all the bystanders too were filled with wonder at his wisdom, thinking that he was inspired."42

At this point, before the truth of Merlin's second prediction can be substantiated, but at the very moment when all the witnesses are convinced of his prophetic power, Geoffrey ends the chapter and begins the $P M$, thus leaving his readers hanging just like the king and his counselors, while he pronounces his second dedication, to Alexander of Lincoln:

Alexander bishop of Lincoln, my love for your noble person compelled me to translate from British into Latin the prophecies of Merlin ... because I was sure that the discernment of your subtle mind would grant me pardon, I have put my rustic pipe to my lips and, to its humble tune, have translated the tongue which is unknown to you. I am surprised that you deigned to entrust this task to my poor pen when your staff of office can command so many men of greater learning to soothe the ears of your intellect with the sweetness of a more sublime song. And to say nothing of all the scholars in the whole of Britain, I readily admit that you alone could sing it best of all with your bold lyre, if your lofty office did not call you to other business. Since it is your wish, therefore, that the reed of Geoffrey of Monmouth pipes this prophecy, please favour his playing and with the rod of your muses restore to harmony anything irregular or faulty. ${ }^{43}$

$D G B$, vi.108.576-77: "Ammirabantur etiam cuncti qui astabant tantam in eo sapientiam, existimantes numen esse in illo."

$43 D G B$, Prologus in Prophetias Merlini 110.8-9, 13-24: "Coegit me, Alexander Lincolniensis praesul, nobilitatis tuae dilectio prophetias Merlini de Britannico in Latinum transferre ... quoniam securus eram ueniae quam discretio subtilis ingenii tui donaret, agrestem calamum meum labellis apposui et plebia modulatione ignotum tibi interpretatus sum sermonem. Admodum autem ammiror quia id pauperi stilo dignatus eras committere, cum tot doctiores uirga potestatis tuae coherceat, qui sublimioris carminis delectamento aures mineruae tuae mulcerent. Et ut omnes philosophos totius Britannuae insulae praeteream, tu solus es, quod non erubesco fateri, qui prae cunctis audaci lira caneres, nisi te culmen honoris ad cetera negocia uocaret. Quoniam ergo placuit ut Galfridus Monemutensis fistulam suam in hoc uaticinio sonaret, modulationibus suis fauere non diffugias et siquid inordinate siue uitiose protulerit ferula camenarum tuarum in rectum aduertas concentum." 
Here, as in the dedication to the $D G B$, a magisterial example of the humility topos, Geoffrey's style is at its most florid. By evoking the pipe of Pan and the Muses, it places both Alexander and Geoffrey within a classical context, as though to balance the very non-classical effect of the prophecies to follow. The claim that Alexander, with his bold lyre, could perform the task better, and the invitation to the bishop to correct anything "irregular or faulty", are disingenuous to say the least, since Geoffrey has already established that the language of the prophecies is unknown to Alexander. The dedication thus invokes the potentially protective authority of Alexander and the church for a literary endeavor which is entirely Geoffrey's own.

The dedication completed, Geoffrey returns briefly to narration: two dragons, one red and one white, emerge from the pool and begin to fight; the white one appears to be winning, but the red one soon gains the upper claw. Vortigern demands to know the meaning of the omen; Merlin's response begins,

\begin{abstract}
Alas for the red dragon, its end is near. Its caves will be taken by the white dragon, which symbolises the Saxons whom you have summoned. The red represents the people of Britain, whom the white will oppress. Its mountains will be levelled with the valleys, and the rivers in the valleys will flow with blood. Religious observance will be destroyed and churches stand in ruins. At last the oppressed will rise up and resist the foreigners' fury. The boar of Cornwall will lend his aid and trample the foreigners' necks beneath his feet. ${ }^{44}$
\end{abstract}

The prophecies carry on in this vein for pages, finally coming to a close with a sort of astrological apocalypse, a "baroque fantasy of cosmic collapse", in Mark Williams' words: ${ }^{45}$

Lightning bolts will flash from Scorpio's tail and Cancer will quarrel with the sun. Virgo will mount on Sagittarius' back and defile her virginal flowers. The moon's chariot will disrupt the zodiac and the Pleiades burst into tears. Janus will not perform his duties, but will close his door and hide in the precinct of Ariadne. In the flash of its beam, the seas will rise and

$44 D G B$, Prophetiae 112.34-40: "Vae rubeo draconi; nam exterminatio eius festinat. Cauernas ipsius occupabit albus draco, qui Saxones quos inuitasti significat. Rubeus uero gentem designat Britanniae, quae ab albo opprimetur. Montes itaque eius ut ualles aequabuntur, et flumina uallium sanguine manabunt. Cultus religionis delebitur, et ruina ecclesiarum patebit. Praeualebit tandem oppressa et saeuiciae exterorum resistet. Aper etenim Cornubiae succursum praestabit et colla eorum sub pedibus suis conculcabit."

M. Williams, Fiery Shapes, p. 92. 
the dust of the long-dead will be reborn. The winds will contend with a terrible blast and the stars will hear them howl. ${ }^{46}$

Geoffrey's vision of the future, inserted into a vision of the past, thus ends with a vision of the end of times.

At this point, he returns to narrative mode, noting that these prophecies (and, he teasingly adds, haec et alia, "and more", which he evidently did not see fit to transcribe ${ }^{47}$ provoke admiration at the ambiguity of Merlin's expressions: "his riddling words reduced the bystanders to amazement." 48 Vortigern asks Merlin to interpret the prophecy with regard to his own fate, and Merlin responds that he should flee the sons of Constantinus (Aurelius Ambrosius and Uther Pendragon) who are already on their way to retake Britain; each will reign in succession, but each will die by poison, only to be avenged by the aper Cornubiae, "the boar of Cornwall". 49 The next day, Ambrosius and Uther do indeed arrive, and not long after, Vortigern is burned to death in his tower. In this way, Geoffrey models for his readers the interpretation of Merlin's prophecies: Ambrosius and Uther are avenged by Arthur, whom any reader must therefore identify as the boar of Cornwall, born as he was at Tintagel.

The prophecies fall into three parts. The first is the "Omen of the Dragons", interpreted for Vortigern by Merlin himself.50 The version in the Historia Brittonum is brief and clear without being explicit when Ambrosius explains it: "the red serpent is your dragon, but the white dragon belongs to those people who invaded many nations and regions of Britain, and held them almost from sea to sea: but eventually, our people will rise up and forcefully cast out the Saxon race from beyond the sea."51 For the Welsh author, writing in the 9th century, this event was still in the future; his prediction is the origin of the so-called Breton or British hope, the hope that the kingdom of Britain might

$46 \quad D G B$, Prophetiae 117.298-304: "Cauda Scorpionis procreabit fulgura, et Cancer cum sole litigabit. Ascendet Virgo dorsum Sagitarii et flores uirgineos obfuscabit. Currus lunae turbabit zodiacum, et in fletum prorumpent Pleiades. Officia Iani nulla redibunt, sed clausa ianua in crepidinibus Adriannae delitebit. In ictu radii exurgent aequora, et puluis ueterum renouabitur. Confligent uenti diro sufflamine et sonitum inter sidera conficient."

$47 \quad D G B$, viii.118.1.

$48 D G B$, viii.118.1-2: "ambiguitate verborum suorum astantes in ammirationem commovit."

$49 \quad D G B$, viii.118.20-21.

5 O $D G B$, Prophetiae 112.34-43.

$5^{1} \quad$ Historia Brittonum (Harley 3859) §42, ed. Faral, $L L A$, pp. 2-62, at p. 32: "Vermis rufus draco tuus est ... at ille albus draco illius gentis quae occcupavit gentes et regiones plurimas in Brittania, et pene a mari usque ad mare tenebunt, et postea gens nostra surget, et gentem Anglorum trans mare viriliter deiciet." Translation mine. 
be regained by the Britons themselves, the Welsh or their Breton cousins who had migrated across the channel. ${ }^{52}$ Geoffrey's revised version of the prophecy places it in the past, in the days of Arthur, the Boar of Cornwall: "The islands of the ocean will fall under his sway and he will occupy the glades of France. The house of Rome will tremble before his rage, and his end shall be unknown."53 Arthur's exploits in Europe and his attempted conquest of Rome are described in Book X, and his uncertain end in Book XI, when he is both letaliter uulneratus, "mortally wounded", and taken away ad sananda vulnera sua, "to have his wounds healed", in the Island of Avalon. ${ }^{54}$ For Geoffrey, the hope of Britain has already come and gone, and whether it will come again remains shrouded in several kinds of mystery.

The next section of the $P M(\S \S 112-13)$ maps the centuries between the death of Arthur and Geoffrey's own time. Orderic Vitalis found it easy enough to identify the figures in these prophecies:

Men well read in histories can easily apply his predictions, if they know the lives of Hengist and Katigern, Pascent and Arthur, Aethelbert and Edwin, Oswald and Oswy, Caedwalla and Alfred, and other rulers of the Angles and Britons ...55

A reader more skeptical than Orderic will immediately perceive that it is no wonder that the first set of prophecies, covering the period from the Saxon invasion to the death of Cadwaladr, were proven true, since they correspond exactly to the narrative of the $D G B$ from this point onward; Merlin, after all, speaks through Geoffrey, who was certainly a "man well read in history", in the very same histories Orderic, too, had read. Indeed, $P M$ \$112.43-61 describes events that will come to pass in Books XI and XII of the $D G B$; Arthur is succeeded, as predicted, by six kings. The "wolf from the sea who will be accompanied by the forests of Africa" of $P M \$ 112.45$ is revealed in Book XI.184.124 as the king of a tribe of Africans settled in Ireland;56 the man of bronze

$5^{2}$ For the Normans' use of Breton auxiliary forces during the Conquest, see Flood, Prophecy, pp. 39-40.

$53 \quad D G B$, Prophetiae 112.41-42: "Insulae occeani potestati ipsius subdentur, et Gallicanos saltus possidebit. Tremebit Romulea domus saeuiciam ipsius, et exitus eius dubius erit."

$54 \quad D G B, x i .178 .81-82$.

55 Orderic Vitalis, Ecclesiastical History xii.47.493, ed. and trans. Chibnall, vol. 6, pp. 386-87: "Historiarum gnari eius dicta facile poterunt intelligere, qui nouerint ea quae contigerunt Hengist et Catigirno, Pascent et Arturo, Aedelberto ac Edwino, Oswaldo et Osuio, Cedwal et Elfredo, aliisque princibus Anglorum et Britonum ..."

$5^{6} D G B$, Prophetiae 112.45 "aequoreus lupus quem Affricana nemora comitabuntur". This is probably the earliest example of the conflation of Irish and African ethnicities which 
(PM §112.55) above the gates of London resolves into King Cadwallo, whose embalmed body, encased in bronze, is erected by his people as a "terror to the Saxons". ${ }^{57}$ Cadwallo's son, Cadwaladr, the last of the kings of Britain according to the $D G B$, travels to Rome upon the command of an angelic voice, as predicted by Merlin: "A blessed king will prepare a fleet and be numbered among the saints in the palace of the twelfth. There will be grievous desolation in the kingdom ..." ${ }^{58}$ At this point, Geoffrey's Merlin has predicted the entirety of the history that Geoffrey was himself engaged in writing, a curious bit of narrative sleight of hand. ${ }^{59}$ Inevitably, these prophecies must be read as truth revealed, since they are revealed as such in the books that follow them. They also prepare the ground, and the reader's imagination, for the prophecies of $\S 113$.

These prophecies are populated with the same kinds of wildlife and meteorological events as those that came before, but they describe the years leading up until the moment of Geoffrey's composition of the $D G B$ in the 113os, thus becoming involved in the politics of the day, rather than in the history of centuries past. Merlin predicts the Norman Conquest, evoking the characteristic armor of the Normans: "The German dragon will be hard put to keep possession of its caves, since retribution will be visited on its treason. Then it will prosper for a short time, but Normandy's tithe will injure it. A people will come clad in wood and tunics of iron to take vengeance on its wickedness." ${ }^{60}$ As Flood points out, Geoffrey here makes a significant addition to the "Omen of the Dragons" when he makes the German dragon guilty of treason; the reference is to Harold Godwinson, who was supposed (by the Normans) to have sworn fealty to Duke William after being shipwrecked on the coast of Normandy, providing one of the excuses for the Norman Conquest. ${ }^{61}$ This addition makes the Normans into rightful rulers rather than unjust invaders. Orderic Vitalis was quick to interpret the rest of this passage:

was to become popular in English propaganda during the period of the Great Hunger in Ireland in the mid-19th century.

$57 D G B$, xi.510: "in terrorem Saxonibus".

$5^{8} \quad D G B$, Prophetiae 112.6o-62: "Rex benedictus parabit nauigium et in aula duodecimi inter beatos annumerabitur. Erit miseranda regni desolatio ..."

59 On prophesying the past, see R. Trachsler, "Vaticinium ex eventu, ou comment prédire le passé: observations sur les prophéties de Merlin", Francofonia 45 (2003), 91-108.

6o $\quad D G B$, Prophetiae 113.69-73: "Vix obtinebit cauernas suas Germanicus draco, quia ultio prodicionis eius superueniet. Vigebit tandum paulisper, sed decimatio Neustriae nocebit. Populus namque in ligno et rerreis tunicis superveniet, qui uindictam de nequitia ipsius sumet."

$61 \quad$ Flood, Prophecy, p. 38. 
For clearer than daylight to the thinking man are the words about the two sons of William, which run, "There shall follow two dragons" - that is, licentious and warlike lords - "of whom one will be slain by the dart of envy" - that is, William Rufus by the arrow while hunting - "the other" that is, Duke Robert, will die "under the shadow of prison, bearing the empty honour of his former title" - that is, of the duke. "Then shall come the Lion of Justice", which is applied to Henry, "at whose roar the towers of Gaul shall shake and the island dragons shall tremble", because by his wealth and power he surpasses all who have reigned before him in England. ${ }^{62}$

Merlin's description of the reign of the Lion of Justice, Henry I, who was still alive as of Orderic's writing, is a masterpiece of ambiguity. It has utopian elements ("in his time gold will be extracted from the lily and the nettle, and silver shall drip from the hooves of lowing cattle",63 and "the greed of kites will be ended and the teeth of wolves blunted"64); these are balanced by more ominous predictions: Humanitas supplicium dolebit. ${ }^{65}$ Wright translates this last phrase as "men will suffer punishment", which allows the interpretation that they are being justly punished by a king who stands for the rule of law; Faletra's translation, perhaps more literal, is less positive: "humankind will mourn its dire straits." 66 The phrase "the lion's cubs will become fishes of the sea" is taken by Orderic and later writers as referring to the drowning of Henry I's only legitimate male heir, William Ætheling, in the White Ship disaster of $1120 .{ }^{67}$

After this point, the prophecies are, inevitably, increasingly obscure, since they are no longer predicting a future familiar to Geoffrey as his own past, and

62 Orderic Vitalis, Ecclesiatical History xii.47.493-94, ed. and trans. Chibnall, vol. 6, pp. 38789: "nam luce clarius patet callenti, quod de duobus Guillielmi filiis dicitur, 'Succedent', inquit, 'duo dracones', domini scilicet libidinosi et feroces. 'quorum alter invidiae spiculo' id est Guillielmus Rufus in venantione sagitta 'suffocabitur, alter' id est Rodbertus dux 'sub umbra' carceris stemma pristini 'nominis' id est ducis gerens perebit. 'succedit leo iustitiae' quod refertur ad henricum 'ad cuius rugitum Gallicanae turres et insulani dracones contremiscent', quia ipse diuitiis et potestate transcendit omnes qui ante illum in Anglia regnaverunt." This passage provides a terminus post quem, since Orderic writes as if Henry I, the Lion of Justice, were still alive; Henry died in 1135 .

$63 D G B$, Prophetiae 113.79-80: "In diebus eius aurum ex lilio et urtica extorquebitur et argentum ex ungulis mugientium manabit."

$64 D G B$, Prophetiae 113.84: "Peribit miluorum rapacitas, et dentes luporum hebetabuntur."

$65 D G B$, Prophetiae 113.82-83.

66 Geoffrey of Monmouth, De gestis Britonum, trans. M.A. Faletra, The History of the Kings of Britain, Geoffrey of Monmouth, Peterborough, Ontario, 2007, p. 133.

$67 D G B$, Prophetiae 113.84-85: "catuli leones in aequoreos pisces transformabatur." 
their style grows increasingly surreal. This did not prevent 12th-century readers from interpreting them. Étienne de Rouen, writing The Norman Dragon (Draco Normannicus) in the late 116os, found in the $P M$ references to the marriage of the princess Matilda to the Emperor Henry v, the death of Stephen, the marriage of Henry and Eleanor, and the conflict between Henry and his sons. ${ }^{68}$ The Eagle of the Broken Covenant was often identified as the Empress Matilda, denied her rightful place as Queen of England. ${ }^{69}$ John of Salisbury, writing to Thomas Becket in the 1170s, refers to Henry II as the Eagle, although Crick notes that he may have been being ironic. ${ }^{70}$

Vernacular writers appear to have been more suspicious of the prophecies. In the first translation of the $D G B$ into Old French, composed around 1155, Wace notoriously refused to include them: "I do not wish to translate his book, for I do not know how to interpret them." "71 Lazamon, translating Wace into English around 1200, follows suit. Blacker suggests that this reluctance may stem from the fact that Wace, as a vernacular writer and self-described clerc lisant for the royal family of Henry II, may have been so dependent on Henry's goodwill that he dared not risk antagonizing the king with even a hint of criticism or a less than glorious future, such as that which various of Merlin's prophecies suggested. ${ }^{72}$ It is also possible that Wace, engaged in a translation of the story of the British people from Troy to the conquest of Britain by the Anglo-Saxons, saw the prophecies, as modern readers are inclined to do, as a distraction from the larger narrative impulse of Geoffrey's work..$^{73}$ Finally, the status of prophecy itself within the larger narrative is extremely dubious, a fact which may have contributed to Wace's unease.

Merlin's prophecies appear as part of the Arthurian section of the $D G B$, the most read and most influential part of the narrative; Merlin is, after all,

68 J. Blacker, "Where Wace Feared to Tread: Latin Commentaries on Merlin's Prophecies in the Reign of Henry II", Arthuriana 6:1 (1996), 36-52, at p. 37.

69 R. Taylor, Political Prophecy, p. 23; Faletra, "Narrating the Matter of Britain", p. 77; M.J. Curley, Geoffrey of Monmouth (Twayne's English Authors Series, 509), New York, 1994, p. 77 .

70 Crick, "Geoffrey and the Prophetic Tradition", p. 73.

71 Wace, Roman de Brut, trans. J. Weiss, Wace's Roman de Brut: A History of the British: Text and Translation (Exeter Medieval English Texts and Studies), Exeter, 1999, rev. ed. 2002, p. 191, li.7539-40 (French text adapted from Wace, Roman de Brut, ed. I.D.O. Arnold, 2 vols., Paris, 1938-40): "Nel vul sun livre translater / Car jo nel sai interpreter."

72 Blacker, "Where Wace Feared to Tread", pp. 44-45.

73 It is clear, however, that many scribes saw the $P M$ as the main event within the $D G B$; see, for example, Auxerre, Bibliothèque Municipale, 91 , fols. $142-53$, in which the prophecies are rubricated; see also Crick, $S C$, p. 331. 
Arthur's prophet and magician, and Arthur himself, as we have seen, is the subject of the first prophecy, the Boar of Cornwall. As Siân Echard reminds us, however, there is a great deal more to the $D G B$ than the Arthurian material; ${ }^{74}$ it springs rather from the tale of the Trojan diaspora, and very particularly from the Aeneid. As in the Aeneid, prophecy is a concern of the text from its first pages. If the $D G B$ is read not as a free-standing text but as part of a much larger literary project, a response to or continuation of the Aeneid, then its significance is deeply altered. The hinge of the Aeneid - the point at which the hero's destiny shifts to assume its full, imperial potential - occurs when Aeneas journeys to the underworld in Book VI and receives Anchises' prophecy about the future of Rome. The $P M$, as Tatlock pointed out long ago, forms a similar hinge in the $D G B$, also coming in the center of the narrative, right before the rise of Uther Pendragon and the birth of Arthur, who is the epitome of imperial British ambition. ${ }^{75}$ Reading the $P M$ against Books III and vi of the Aeneid reveals a slippery quality to prophecy within the text, one which is not apparent in the $P M$ read alone.

The $D G B$ begins with a prophecy: Brutus will kill both of his parents and wander the world in exile before achieving the highest honor. ${ }^{76}$ This prediction is fulfilled in Book I: Brutus's mother dies giving birth to him, and he kills his father accidentally while hunting. The second prophecy is more problematic. On a deserted island, Brutus invokes the goddess Diana, who responds to his prayer:

Brutus, to the west, beyond the kingdoms of Gaul,

lies an island of the ocean, surrounded by the sea;

an island of the ocean, where giants once lived,

but now it is deserted and waiting for your people.

Sail to it; it will be your home for ever.

It will furnish your children with a new Troy.

From your descendants will arise kings, who

will be masters of the whole world. ${ }^{77}$

74 See S. Echard, "Geoffrey of Monmouth", in Echard (ed.), The Arthur of Medieval Latin Literature, pp. 45-66, at pp. 45-46, for Geoffrey. On the Virgilian elements in Geoffrey's book, see R. Waswo, "Our Ancestors, The Trojans: Inventing Cultural Identity in the Middle Ages", Exemplaria 7:2 (1995), 269-9o, at pp. 279-82.

Tatlock, $L H B$, p. 403 .

$76 \quad D G B$, i.6.57-59.

$77 D G B$, i.16.305-12: "Brute, sub occasu solis trans Gallica regna / insula in occeano est undique clause mari; / insula in occeano est habitata gigantibus olim, / nunc deserta quidem, gentibus apta tuis. / Hanc pete; namque tibi sedes erit illa perhennis. / Hic fiet natis 
Diana's prophecy has clear parallels with the oracle her brother Apollo gives in Book III of the Aeneid:

Sons of Dardanus, hardy souls, your fathers' land that gave you birth will take you back again, restored to her fertile breast.

Search for your ancient mother. There your house, the line of Aeneas, will rule all parts of the world ...78

Each promises the hero a homeland from which his descendants may grow to rule the world, in very similar language. The prophecy in the Aeneid, however, quickly proves misleading. Anchises interprets it as referring to Crete, but as soon as Aeneas begins to build a city there, it is stricken by plague. In a dream, the Lares and Penates clarify: the "ancient mother" is not Crete, but Italy, and the Trojans sail on. Diana's prophecy, by contrast, does not misdirect Brutus, although it certainly misinforms him. Faletra points out the "great contradiction" of Diana's speech: the giants are still very much alive in Britain, as Brutus will discover when he eventually gets there. ${ }^{79}$

The misleading qualities of Diana's speech should direct our attention to the problems of predicting the future, even within a narrative whose end is known (the foundation of Britain by Brutus is as inevitable as the foundation of Rome by Aeneas). Unlike Apollo's prophecy, Diana's is not merely misinterpreted, it is wrong. She does not declare that the island is uninhabited, which might, in a pinch, be understood as uninhabited by humankind; rather, she states explicitly that the island is now (nunc) deserted, although it was once (olim) occupied by giants. This flat untruth is followed by two predictions capable of bearing multiple interpretations. The first is the promise that Britain will be the eternal (perennis) seat of Brutus and his descendants; the second is that Brutus's heirs "will be masters of the whole world" ${ }^{80}$ Many readers have taken this to refer to the conquest of Rome by Brennius, or to the conquests of Arthur, but the geography of the narrative itself makes this doubtful, since

altera Troia tuis. / Hic de prole tua reges nascentur, et ipsis / tocius terrae subditus orbis erit."

78 Virgil, Aeneid iii.94-98, ed. R.A.B. Mynors, P. Virgili Maronis Opera, Oxford, 1969: "Dardanidae duri, quae vos a stirpe parentum / prima tulit tellus, eadem vos ubere laeto / accipiet reduces. Antiquam exquirite matrem: / hic domus Aeneae cunctis dominabitur orbis, / et nati natorum, et qui nascentur ab illis." Translation from Virgil, Aeneid, trans. R. Fagles, New York, 2006, p. 104.

79 Faletra, "Narrating the Matter of Britain", p. 71.

8o $D G B$, i.16.311-12: "ipsis / tocius terrae subditus orbis erit." 
"the whole earth" should encompass those lands east of Rome through which Brutus himself has recently traveled. The only descendant of Brutus whom this part of the prophecy can be said accurately to describe is Constantinus, British through his mother Helen. That Britain will be the everlasting possession of the Trojans is even more problematic, given that the entire thrust of Geoffrey's narrative is directed toward proving that the British no longer rule nor deserve to rule in the island, but have been supplanted by the Anglo-Saxons, and eventually the Normans. In apparent contradiction of the angelic voice that speaks to Cadwaladr at the end of the $D G B$, promising that "through his blessing the British people would one day recover the island, when the prescribed time came", Geoffrey insists flatly at the end of the book that "the Welsh, unworthy successors to the noble Britons, never again recovered mastery over the whole island." ${ }^{81}$ If the future promised by Diana's prophecy and reasserted by the angelic voice is to come to pass, in other words, it does not appear to have done so in the narrative circumscribed by Geoffrey's $D G B$ - not, at any rate, for Brutus's British descendants. If, however, Diana's prophecy is read as promising Britain perennially to the descendants of Troy, rather than specifically to the British descendants of Troy, the difficulty disappears: the Normans had been Trojan ever since the 11th century, when Dudo of St Quentin provided them with a genealogy extending back to Antenor. ${ }^{82}$ Prophecy's slippery nature, its openness to interpretation, is precisely what made the $P M$ so variously useful to different audiences throughout the ages. This hermeneutic instability, present already in Diana's prophecy, is simply carried to new heights in the $P M$, and here again the Virgilian intertext is instructive. ${ }^{83}$ Indeed, it may well be from Virgil that Geoffrey learned the trick of predicting the past.

$81 \quad D G B$, xi.205.568-69: "Dicebat etiam populum Britonum per meritum suae fidei insulam in futuro ademptum postquam fatale tempus superveniret"; $D G B, x i .205 .598-99$ : "Degenerati autem a Britannica nobilitate Gualenses numquam postea monarchiam insulae recuperauerunt."

82 Dudo of St Quentin, The Customs and Deeds of the First Dukes of the Normans, ed. J. Lair, De moribus et actis primorum Normanniae ducum auctore Dudone Sancti Quintone decano, Caen, 1865, p. 13 .

83 A secondary example of such instability occurs in the case of the prophetic Eagle of Shaftesbury. Geoffrey refers twice to this bird; the first time he dismisses its prophecies ( $D G B$, ii.36.32-34), but the second ( $\left.D G B, x i .218 .575^{-78}\right)$ they provide confirmation of the authority of the Holy Voice that speaks to Cadualadrus. In the decades after the appearance of the $D G B$, a quasi-independent Prophecy of the Eagle evolved, often attaching itself to manuscripts of the $D G B$; see Crick, $D R$, pp. 65-66 and A.F. Sutton and L. Visser-Fuchs, "The Dark Dragon of the Normans: A Creation of Geoffrey of Monmouth, Stephen of Rouen, and Merlin Silvester", Quondam et Futurus: A Journal of Arthurian Interpretations 2:2 (1992), 1-19, at pp. 2-4. 
The $P M$ and the vision of Roman futurity in Aeneid Book vi are linked not only by their positions in the two texts, but also thematically and, although this may not be immediately evident, formally. Structurally, each is the major extended prophecy at the center of a book studded with lesser, or at any rate briefer, prophecies. In the $D G B$, as we have seen, Diana's oracle at the beginning and the angelic voice at the end predict the future of the descendants of Brutus. The situation in the Aeneid is more complicated. As Sarah Mack notes, "there are two futures in the poem and two sorts of prophecy to express them. First, and most commonly predicted, is the immediate future, which is revealed in short and fairly limited prophecies ... The other future in the poem is the distant future centering on Rome from its foundation to Augustan times." 84 Into the first category fall the prophecies of Hector and Creusa in Aeneid Book II, those of Apollo (corrected by the Lares and Penates and expanded by Celaeno) and Helenus in Book III, of Tiber in Book VIII, and so forth. Mack identifies these as "directional prophecies" which move Aeneas from one point to the next on his journey toward Italy and the foundation of Rome, and notes that while they do come true, they are in most cases misleading and excessively optimistic. ${ }^{85}$ The "Roman" prophecies, on the other hand (Jupiter's in Book I, Anchises' central revelation in Book VI, and the ekphrastic prophecy of Aeneas's shield in Book VIII) "exist outside of the narrative of the poem". ${ }^{86}$ They narrate the future not of the individual hero but of Rome, the nation Aeneas will found. They are also, importantly, narrations about the remote future from the point of view of the protagonist, Aeneas; he cannot, indeed, be expected to understand much of what Anchises reveals to him in the underworld. Simultaneously, of course, from the perspective of the author, the prophecies narrate the past, and even the very recent past: the civil wars from which Rome had emerged during Virgil's lifetime.

Anchises' prophecy takes the form of a genealogy, not of a person but of Rome itself; the succession of figures he displays are sometimes father and son, but more often linked by their assumption of imperium: all are sons of the Rome that was, fathers of the Rome that will be. The $P M$ often also takes this pseudo-genealogical form: "His six successors will wield the sceptre"; 87 "The sixth will overthrow the city walls of Ireland and turn its forests into a plain." 88 It is true that the two texts initially appear to have little in common stylistically.

\footnotetext{
84 S. Mack, Patterns of Time in Virgil, Hamden, CT, 1978, p. 56.

85 Mack, Patterns of Time, pp. 56-57.

86 Mack, Patterns of Time, p. 67 .

$87 \quad D G B$, Prophetiae 112.43-44: "Sex posteri eius sequentur sceptrum."

$88 D G B$, Prophetiae 114.99-100: "Sextus Hiberniae moenia subuertet et nemora in planiciem mutabit."
} 
Merlin's prophecies are in unruly prose and teem with unidentifiable figures and strange beasts like the hedgehog of $\$ 116.175^{-76}$, who hides apples and constructs pathways beneath the city of London, while Aeneid vi proceeds in dignified hexameters, summoning up an orderly parade of Roman dignitaries. Or so it would seem, but it is important to recognize that the classical past is in many ways much closer to its 21st-century readers than it was to Geoffrey in the 12th. The following passage might have been as opaque to medievals as Geoffrey's prophecies are to moderns:
But you see that pair of spirits? Gleaming in equal armor, equals now at peace, while darkness pins them down, but if they should reach the light of life, what war they'll rouse between them! Battles, massacres ... ... the bride's father, marching down from his Alpine ramparts, Fortress Monaco ... her husband set to oppose him with the armies of the East! 89

Any modern commentary will identify these two figures as Caesar and Pompey (Pompey was married to Caesar's daughter, and their alliance disintegrated after her death). But would the allusion have been evident to a 12th-century reader? Servius identifies Caesar and Pompey. Fulgentius, whose allegorizing interpretation may have been especially popular in the British Isles, does not. Without commentary, or with a commentary not based upon Servius, this passage is not so different in substance from a passage like the following:

The island will be soaked in nightly tears, and so all men will be provoked to all things. Their progeny will try to fly beyond the heavens, but the favour of new men will be raised up. The possessor will be harmed by the goodness of the wicked until he dresses himself as his father. ${ }^{90}$

89 Virgil, Aeneid vi.824-29, ed. Mynors: "illae autem paribus quas fulgere cernis in armis, / concordes animae nunc et dum nocte prementur, / heu quantum inter se bellum, si lumina vitae / attigerint, quantas acies stragemque ciebunt / aggeribus socer Alpinis atque arce Monoeci / descendens, gener adusersis instructus Eois!" Virgil, Aeneid, trans. Fagles, p. 197. Fagles supplies the names of Caesar and Pompey, in the places marked by elision in my citation.

$90 \quad D G B$, Prophetiae 114.87-9o: "Nocturnis lacrimis madebit insula, unde omnes ad omnia prouocabantur. Nitentur posteri transuolare superna, sed fauor nouorum sublimabitur. Nocebit possidenti ex impiis pietas donec sese genitore induerit." 
The contrast between night on earth and heavenly glory marks both passages, as does the reference to fathers and sons. Or, to take another example, Anchises describes the construction of the walls of Rome in the following lines:

... watch,

my son, our brilliant Rome will extend her empire far and wide as the earth, her spirit high as Olympus.

Within her single wall she will gird her seven hills ... ${ }^{91}$

Geoffrey's Merlin describes another city: "London will be filled with envy and will increase its walls threefold. The Thames will form a moat around the city ...."92 In both of these passages, cities fortify themselves. I do not argue here for direct influence of one passage on the other but simply that the flavor of Anchises' prophecy is not so different from that of Merlin's, if one accounts for the greater un-interpretability of the vision of Roman futurity to its medieval readers. Geoffrey, in other words, may have thought his prophetic text was more like Virgil's than we do. His inspiration is literary as much as it is either prophetic or political, regardless of the uses to which his texts were turned. He was, after all, in some important sense, writing a sequel to the Aeneid.

The very indeterminacy of the $P M$ proved, finally, to be its greatest strength, the source of its longevity. By creating a text so marvelously open to interpretation, Geoffrey in fact created a magisterial role for himself: the authority of his vision of the British past and future, located in lost books in other languages, finally depended entirely on its own uniqueness, on the fact that it was a vision accessible only through Geoffrey himself. The author himself thus comes to function not only as historian but also as prophet, possessed of privileged access to knowledge about both the past and the future. With regard to his own text, he plays the role of a Merlin, or indeed of a Virgil, who was respected in the Middle Ages as seer, magician, and prophet, ${ }^{93}$ an expanded role which recalls the identity of history and prophecy within the Welsh tradition. ${ }^{94}$ In the centuries after Geoffrey's death, the $P M$ was deployed to legitimize the accession of the Tudors, as we have seen, but also in support of Robert the Bruce in

91 Virgil, Aeneid vi.781-83, ed. Mynors: "en huius, nate, aspiciis illa inluta Roma / imperium terris, animos aequabit Olympo, / septemque una sibi muro circumdabit arces ..." Virgil, Aeneid, trans. Fagles, p. 197.

$92 \quad D G B$, Prophetiae 116.174-76: "Inuidebit ergo Lundonia et muros suos tripliciter augebit. Circuibit eam undique Tamensis fluuius ..."

93 On Virgil's magical powers, see J. Wood, "Virgil and Taliesin: The Concept of the Magician in Medieval Folklore", Folklore 94:1 (1983), 91-104.

94 A.L. Jones, Darogan, p. 2. 
his rebellion against Edward I. ${ }^{95}$ Across the Channel, the prophecies were often cited by the French to the detriment of the English during the Hundred Years' War: Eustaches Deschamps composed a ballad "De la prophecie Merlin sur la destruction d'Angleterre qui doit bref advenir" 96 and Joan of Arc was identified with the mysterious girl from the "city of the holy forest", although she herself apparently put little stock in prophecy. ${ }^{97}$ A Catalan "Profecia de Merlin" from around 1370 comments on the successors of Alfonso X. ${ }^{98}$ In "To the Majesty of King James", Drayton recognized the first Stuart king as the prince who "as their great Merlin prophesied before / Should the old Britons regality restore", ${ }^{\prime 9}$ while in the 17th and 18th centuries the once lofty tradition devolved into a series of "prophecies of Merlin" which consisted of horoscopes and other popular prognostications. ${ }^{100}$ Nor has the phenomenon run its course: as recently as 2010, the American tabloid Sun published an article on Merlin's prophecies, recently unearthed by archaeologists and "just translated", predicting everything from the Great Recession to global warming. ${ }^{101}$ The Prophetiae Merlini continues to speak, even to the 21st century.

95 N. Gallagher, "The Franciscans and the Scottish Wars of Independence: An Irish Perspective", Journal of Medieval History $3_{2}^{2}$ (2006), 3-17, at p. 9.

96 Zumthor, Merlin le Prophète, p. 68.

$97 \quad D G B$, Prophetiae 116.155-56: "ex urbe canuti nemoris". On Joan, see Zumthor, Merlin le Prophète, pp. 69-70 and C. Daniel, "L'audience des prophéties de Merlin: entre rumeurs populaires et textes savants", Mediévales: Langues, Textes, Histoire 57 (2009), 33-51, at pp. $42-46$.

98 Zumthor, Merlin le Prophète, p. 77. See also pp. 432-36 in this volume.

99 A. McRae and J. West (eds.), Literature of the Stuart Successions: An Anthology, Manchester, 2017, p. 42.

100 Zumthor, Merlin le Prophète, p. 74.

101 "Disasters! War! Recession! More! 7 Forbidden Prophecies: Mystic Merlin's Secrets Come True", Sun, 11 September 2010, p. 1. 